J. Amer. Soc. Hort. Sci. 116(2):174-178. 1991.

\title{
Carbohydrate Levels and the Development of Fruit in Cranberry
}

\author{
Brian A. Birrenkott' \\ Department of Horticulture, University of Wisconsin-Madison, Madison, WI 53706
}

Cynthia A. Henson ${ }^{2}$

U.S. Department of Agriculture-Agricultural Research Service, Cereal Crops Research Unit, and Department of Agronomy, University of Wisconsin-Madison, Madison, WI 53706

Elden J. Stang ${ }^{3}$

Department of Horticulture, University of Wisconsin-Madison, Madison, WI 53706

Additional index words. Vaccinium macrocarpon, sugars, photosynthates, fruit set

\begin{abstract}
Cranberry (Vaccinium macrocarpon Ait. Cv. Searles) vegetative tissue was analyzed at various stages of development to determine carbohydrate levels under field and greenhouse conditions and to identify the carbohydrates. Except during dormancy, cranberry uprights in the field had the highest concentration of carbohydrates (soluble and starch) at early blossom, when the lower flowers were at anthesis. As early flowers developed into fruit and upper flowers were at or just beyond anthesis, uprights had lower carbohydrate concentrations. As fruit growth slowed, soluble carbohydrate levels increased and were highest at dormancy. Upright shoot tissue produced the previous year and trailing woody stems followed the same trend as the current season's growth but had consistently lower soluble carbohydrate levels at each growth stage. Starch levels were low in current growth and did not change appreciably with fruit development. Starch was primarily stored and subsequently depleted in the previous season's upright growth and trailing woody stems. Tissue from the greenhouse was generally higher in carbohydrates than was field-grown tissue. Fruit developed from $53 \%$ of the flowers under greenhouse conditions, compared to $38 \%$ in the field. Insufficient carbohydrate levels may be responsible for the low fruit set observed in the field. Sucrose, glucose, fructose, raffinose, and stachyose were present in cranberry vegetative tissue.
\end{abstract}

The North American cranberry of commerce is a low-growing, trailing, woody, broadleaf evergreen plant. Cranberry shoots may grow either horizontally or vertically (Eck, 1986). Horizontal stems are called runners due to their vigorous (juvenile) growth habit. Flowers and fruit are borne on erect-growing shoots called uprights. An upright grows vertically without support for only one to two seasons. As it becomes longer, the shoot will either be supported by the mass of other uprights or will bend over at the base with only the apical 10 to $20 \mathrm{~cm}$ remaining upright. Additional vegetative extension results in more of the basal portion of the stem becoming horizontal. Thus, an upright may be $1 \mathrm{~m}$ long and the tip will only stand 10 to $20 \mathrm{~cm}$ high. New uprights may be initiated from axillary buds on runners or on the trailing basal portion of other uprights. Runners and trailing uprights form an intertwining mat of woody stems covering the soil surface. Individual leaves may remain on cranberry vines for 2 to 3 years. There are fewer leaves on 2-yearold than on 1-year-old wood and fewest on older tissue, when stems undergo secondary (woody) growth.

Mixed buds, capable of producing flowers and vegetative

Received for publication 25 Sept. 1989. Research supported in part by the College of Agricultural and Life Sciences, the Graduate School, Univ. of Wisconsin-Madison, and the Wisconsin cranberry industry under the auspices of the Wisconsin Cranberry Board, Inc. We thank DuBay Cranberries, Inc. for their generosity in providing facilities and plantings used in this research. We gratefully acknowledge the technical assistance of Julie Stone, Mike Moser, and Zhuotoa Sun. Mention of a trademark or proprietary product does not constitute a guarantee or warranty of the product by the U.S. Dept. of Agriculture and does not imply its approval to the exclusion of other products that may also be suitable. The cost of publishing this paper was defrayed in part by the payment of page charges. Under postal regulations, this paper therefore must be hereby marked advertisement solely to indicate this fact.

'Graduate Research Assistant. Current address: O.M. Scott \& Sons Co., Dwight G. Scott Research Center, 14310 Scottslawn Road, Marysville, OH 43041. Research Plant Physiologist and Assistant Professor.

${ }^{3}$ Professor. structures, are formed terminally on certain uprights in late summer. Each bud is capable of producing one to seven flowers, as well as leaves and a growing point. The flowers on an individual upright do not open at once but undergo anthesis acropetally. The prolonged flowering period may begin in midJune and last into July, followed by harvest in late September.

Inadequate fruit set limits cranberry productivity. Yield component analyses have shown fruit set to be an important limiting factor in cranberry production (Eaton and Kyte, 1978; Eaton et al., 1983). Normal fruit set in Wisconsin cranberry fields ranges from $30 \%$ to $40 \%$. Pollination of a high percentage of flowers produced a maximum of $38 \%$ fruit set in two consecutive years (Birrenkott and Stang, 1989). Baumann and Eaton (1986) concluded that competition occurs between the berries on an upright, the lower flowers being more likely to develop into fruit. Removal of the lower two flowers from uprights with at least three flowers allowed a greater percentage of set for the remaining flowers (Birrenkott and Stang, 1990). Insufficient pollen tube growth has been suggested as the mechanism by which certain flowers fail to develop into fruit (Birrenkott and Stang, 1989; Demoranville and Deubert, 1987), although the cause has not yet been clearly established. Marucci (1966) proposed that the overproduction of cranberry flowers is due to insufficient energy reserves to allow development of a fruit from every flower. Cranberry uprights tend to bear biennially (Eaton, 1978), providing additional support for the limited-energy theory based on work in other fruit crops (Monselise and Goldschmidt, 1982). After fertilization, the developing cranberry fruit is a strong sink for photosynthates as the ovary rapidly enlarges (Chandler, 1952). Flowers at earlier stages of development would not be as strong sinks as developing fruit and, therefore, may compete unsuccessfully for available carbohydrates.

The objective of this research was to determine if decreased available carbohydrates could be responsible for the observed incomplete fruit set. The approaches used were to 1) determine 
the carbohydrate levels of cranberry vegetative tissue at various stages of fruit development when grown under greenhouse and field conditions, and 2) identify the carbohydrates present in cranberry tissue.

\section{Materials and Methods}

Field samples. Flowering and fruiting uprights at seven stages of development were collected in 1988 from cranberry growing in the field. The seven developmental stages (Fig. 1) were 1) preblossom- 17 June, 2) early blossom- 1 July, 3) late blossom- 11 July, 4) early fruit development-18 July, 5) midfruit development-1 Aug., 6) late fruit development-12 Sept., and 7) dormancy-18 Nov. At each stage, all uprights within a 30 $\mathrm{x} 30-\mathrm{cm}$ area were sampled at four randomly selected locations (replicates) within an area $\approx 15 \times 8 \mathrm{~m}$. Flowering and fruiting uprights at the desired stage of development were separated into current season's growth, previous season's growth, and trailing woody stems (Fig. 2). At all dates, stems with leaves were retained and all developing fruit was removed from current growth. Uprights were taken between $1030 \mathrm{HR}$ and $1200 \mathrm{HR}$, wrapped in cheesecloth, labeled, and placed in liquid nitrogen within 15 min of sampling. After lyophilization, samples were ground in a Wiley mill and passed through a 20 -mesh screen. The samples were redried in a forced-air oven at $70 \mathrm{C}$ for $30 \mathrm{~min}$ before being sealed in bottles for storage at $-20 \mathrm{C}$.

Greenhouse samples. Dormant 'Searles' uprights with flower buds were taken from the field in late fall (18 Nov. 1988) and stored in moist peat in a polyethylene bag for 3 months at $4 \mathrm{C}$. Cuttings were placed in solution culture containing $(\mathrm{mM}) 2.0$ $\left(\mathrm{NH}_{4}\right)_{2} \mathrm{~S} \mathrm{O}_{4}, 0.5 \mathrm{H}_{3} \mathrm{PO}_{4}, 1.3 \mathrm{KNO}_{3}, 1.3 \mathrm{Ca}\left(\mathrm{NO}_{3}\right)_{2} .4 \mathrm{H}, 0$, and $0.5 \mathrm{MgSO}_{4} \cdot 7 \mathrm{H}_{2} \mathrm{O}$. Micronutrients were supplied according to

\section{Cranberry Developmental Stages}

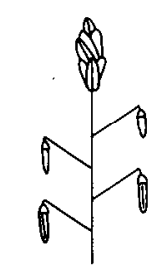

Preblossom (Pb)

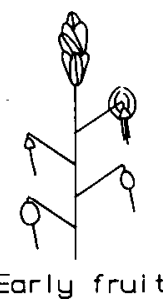

(Ef)

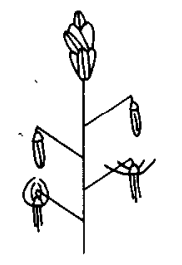

Early blossom

$$
\text { (Eb) }
$$
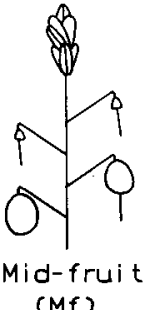

(Mf)

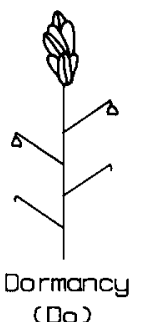

(Do)

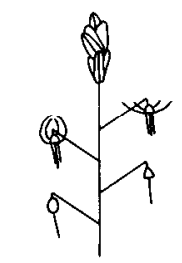

Late blossom
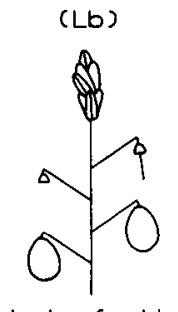

Late fruit (Lf)

Fig. 1. A typical cranberry upright representing the seven stages of development sampled for carbohydrate analyses.

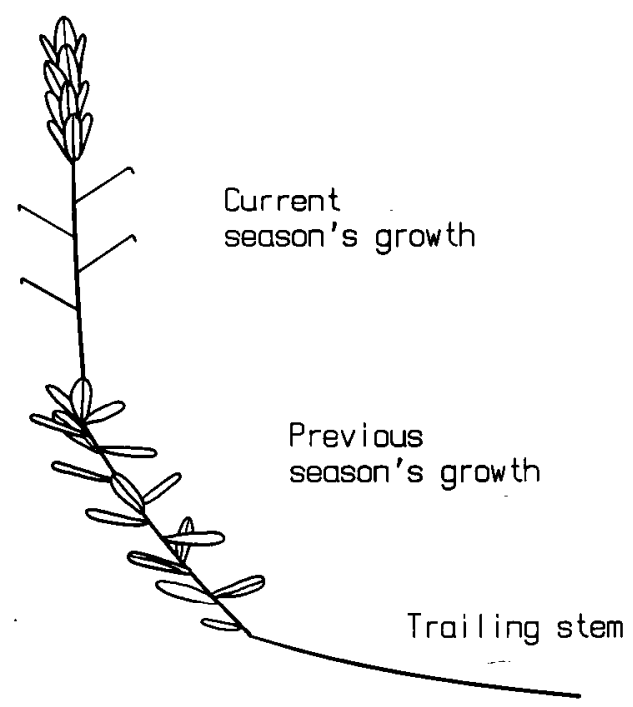

Fig. 2. Portion of a cranberry upright indicating the current season's growth, previous season's growth, and trailing woody stem tissue.

Johnson et al. (1957). Each of 40 two-liter plastic beakers was covered with a styrofoam lid through which nine dormant cuttings were individually suspended in the nutrient solution. $\mathrm{Nu}$ trient solution was constantly aerated and replaced with fresh solution biweekly. Distilled water was added in the interim to maintain solution levels. Natural sunlight was supplemented with three high-pressure sodium lights producing a 14-hr daylength and a photosynthetic photon flux of 800 to $1200 \mu \mathrm{mol} \cdot \mathrm{s}^{-1} \cdot \mathrm{m}^{-2}$, depending on the amount of cloudiness. Temperatures ranged from 18 to $27 \mathrm{C}$ during the day and 13 to $18 \mathrm{C}$ at night. Flowers were hand-pollinated daily by agitating the flowers, allowing pollen to drop on the thumbnail, and subsequently transferring pollen to receptive stigmas.

A pooled sample of 15 uprights was collected at 1) early blossom, 2) late blossom, 3) early fruit development, and 4) midfruit development. Plants were sampled between $1030 \mathrm{HR}$ and 1200 HR and divided into current season's growth, previous season's growth, and roots. Samples were prepared for carbohydrate analysis as described above. A single upright in each beaker, marked at the beginning of the experiment, was used for fruit set determination. Fruit set was calculated from the 40 uprights as the total number of fruit per total number of flowers.

Carbohydrate levels. Ethanol-soluble carbohydrate levels were determined with the anthrone reagent using a modification of the technique described by Yemm and Willis (1954). Soluble carbohydrates were extracted from two subsamples $(200 \mathrm{mg}$ each) of each field replicate or greenhouse sample with $80 \%$ ethanol and incubated at $70 \mathrm{C}$ for $15 \mathrm{~min}$. After centrifugation (9750 x g; $10 \mathrm{rein}$ ), $3 \mathrm{ml}$ of the supernatant was completely evaporated at 50C with an analytical evaporator (Meyer N-Evap). Sugars were resuspended by adding $5 \mathrm{ml}$ of distilled water, mixing vigorously, and placing the tubes for $10 \mathrm{~min}$ in a water bath held at 50C. The total volume was brought to $10 \mathrm{ml}$ with an additional $5 \mathrm{ml}$ of distilled water. The sugar extract was vacuum-filtered through Whatman \#2 filter paper. Clean, dry polyvinylpolypyrrolidone (PVPP) was added to filtrates (200 mg: $4 \mathrm{ml}$ ), stirred for 30 rein, then vacuum-filtered. PVPP was added to remove noncarbohydrate substances that interfered with the carbohydrate assays by either binding to the anthrone reagent or absorbing at $600 \mathrm{~nm}$. PVPP was prepared by boiling in $10 \%$ $\mathrm{HCI}$, rinsing 10 to 15 times with distilled water, and drying overnight in a forced-air oven at $60 \mathrm{C}$. 
The anthrone reagent was prepared by dissolving $200 \mathrm{mg}$ of anthrone (Sigma, St. Louis) in $100 \mathrm{ml}$ of $71.5 \% \mathrm{H}_{2} \mathrm{SO}_{4}$ solution. The reagent was allowed to stand 30 to 40 rein, with occasional swirling, and was freshly prepared each day. Equal amounts $(5 \mathrm{ml})$ of the anthrone reagent and the acid solution without anthrone added were pipetted into separate test tubes and chilled in ice water. The test solution $(0.5 \mathrm{ml})$ was layered on the acid, with and without anthrone added, and cooled for an additional $5 \mathrm{~min}$. The contents of the tubes were thoroughly mixed while being kept cool. After being covered with marbles, the tubes were placed in a boiling water bath for $10 \mathrm{~min}$ before being cooled in tap water. Absorbance at $600 \mathrm{~nm}$ was read with an IBM spectrophotometer (IBM, Danbury, Conn.) using water as a reference. The difference between absorbance with and without anthrone was calculated for each subsample. Glucose standards were prepared and subjected to the same treatments to produce a standard curve. Anthrone-dependent absorbance was converted to glucose equivalents using the standard curve.

Starch. Field tissue at early blossom, early fruit development, and dormancy was analyzed for starch. Tissue at early blossom and early fruit development was used for starch determination in greenhouse samples. Starch in lyophilized tissue $(50 \mathrm{mg})$ was solubilized by boiling for $30 \mathrm{~min}$ in the presence of $0.2 \mathrm{M}$ sodium acetate buffer $(1.7 \mathrm{ml}, \mathrm{pH} 4.5)$. After cooling in tap water, $300 \mu \mathrm{l}$ of buffered amyloglucosidase $(60 \mathrm{IU} / \mathrm{ml})$ from Aspergillus niger (Boehringer Mannheim, Indianapolis), was added to hydrolyze starch to free glucose. Blanks contained buffer in place of amyloglucosidase. The samples, $2 \mathrm{ml}$ final volume, were shaken for $3 \mathrm{hr}$ at $40 \mathrm{C}$ and subsequently terminated by boiling for $30 \mathrm{~min}$. After centrifugation $(1100 \times g ; 10$ rein), the supernatant was filtered through Whatman \#2 filter paper as described earlier. The filtrate was analyzed for glucose calorimetrically using a glucose oxidase, peroxidase-coupled enzyme system (Sigma Diagnostic Kit 315). The amyloglucosidase-dependent difference in absorbance at $505 \mathrm{~nm}$ was converted to starch levels with a standard curve.

Carbohydrate identification. Descending paper chromatography was used to identify the carbohydrates in field samples of current vegetative tissue. at early blossom and dormancy. Sample and standard solutions were spotted onto sheets $(57 \mathrm{X}$ $19 \mathrm{~cm}$ ) of Whatman \#1 Chromatography Paper. Total distance from origin to tip was $44 \mathrm{~cm}$. Papers were placed in a developing tank equilibrated with 6 n-butanol :4 pyridine : 3 water (by volume) for $46 \mathrm{hr}$. The air-dried chromatogram was subjected to alkaline silver nitrate stain (Chaplain, 1986) or an acidic urea stain (Wise et al., 1955).

\section{Results}

\section{Carbohydrate levels}

Field samples. Of the three tissues sampled, current season vegetative tissue varied the greatest in soluble carbohydrate levels (Fig. 3). At early blossom, when only the lower flowers were open, current tissue contained $14.3 \%$ carbohydrate (14.3 $\mathrm{mg}$ glucose equivalents per $100 \mathrm{mg}$ dry tissue). The concentration of carbohydrates declined to $13.2 \%$ at late blossom $(\mathrm{t}=$ $2.76, P<0.05)$. However, this represents a mixture of uprights in which some had developing fruit in the lower positions and others did not. Current growth from a single sample of uprights with developing fruit in one or both of the lower positions contained $11.9 \%$ carbohydrate at late blossom. Except during dormancy, the highest concentration of soluble carbohydrates in

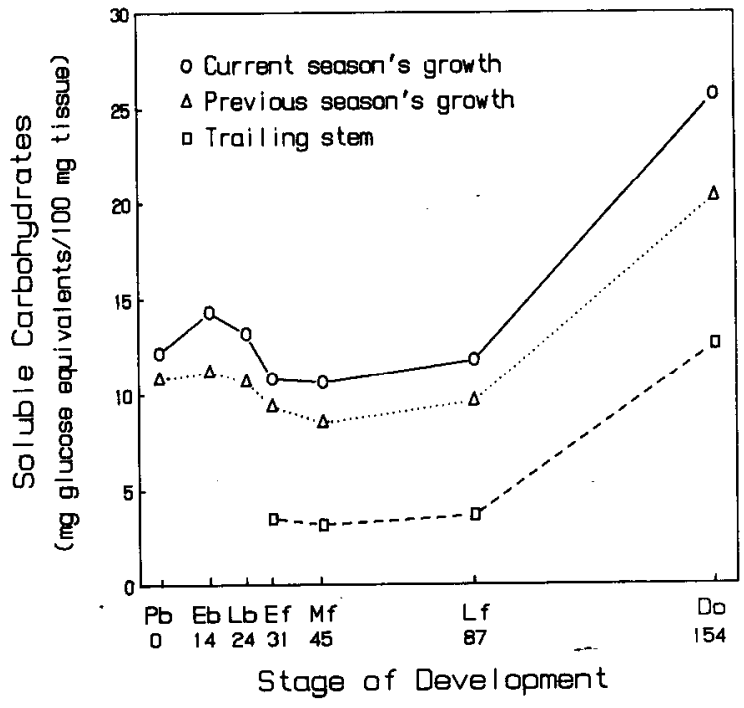

Fig. 3. Changes in the concentration of soluble carbohydrates in 'Searles' cranberry uprights at various stages of development in 1988. Approximate number of days after preblossom is given for each developmental stage. Standard error bars did not exceed the size of the symbols $(\leq 0.5 \mathrm{mg}$ glucose equivalents per $100 \mathrm{mg}$ dry tissue).

uprights was at early blossom, when the lower flowers were at anthesis. As early flowers started to develop into fruit at late blossom, upper, later, flowers were developing on uprights having lower carbohydrate concentrations. At this stage, late flowers were at anthesis or just beyond. Carbohydrate levels in current tissue dropped to their lowest level at early fruit and midfruit development (10.6\%). Continued fruit development did not further deplete carbohydrate levels, which subsequently increased slightly at late fruit development. Cranberry fruit growth is slow at this stage, which is when anthocyanins are being produced (Chandler, 1952; Hawker and Stang, 1985). The concentration of soluble carbohydrates in cranberry vegetative tissue was highest during dormancy. Vegetative tissue produced the previous year followed the same trend as the current season's tissue but had lower soluble carbohydrate levels at each stage. Trailing woody stems, not sampled until early fruit development, followed the same trend as the other two tissues sampled but always contained lower soluble carbohydrate concentrations.

Starch levels varied with tissue type and stage of development (Fig. 4). Current vegetative tissue contained $1.3 \%$ starch at early blossom, with slightly lower levels at early fruit and dormancy stages. Upright growth from the previous year contained 2.6\% starch at early blossom, only to decline by nearly $40 \%$ and $75 \%$ at early fruit development and dormancy, respectively. Similarly, trailing woody stems contained $2.8 \%$ starch at early fruit development and declined to $1.3 \%$ at dormancy.

Greenhouse samples. Greenhouse-grown uprights in solution culture produced more dry matter (data not shown) than uprights grown in the field. At early blossom, carbohydrate concentrations were $14.3 \%$ for current season's growth and $11.2 \%$ for the previous season's upright tissue (Fig. 5). These values were identical to field values at the same developmental stage. At late blossom, however, upright tissue from the greenhouse increased in carbohydrate concentration, whereas carbohydrate concentration decreased in field-grown, current season uprights. In greenhouse tissue at this stage, early flowers had not started developing into fruit (ovaries not visibly enlarged), yet the late flowers had already reached anthesis. Also, new shoots were 


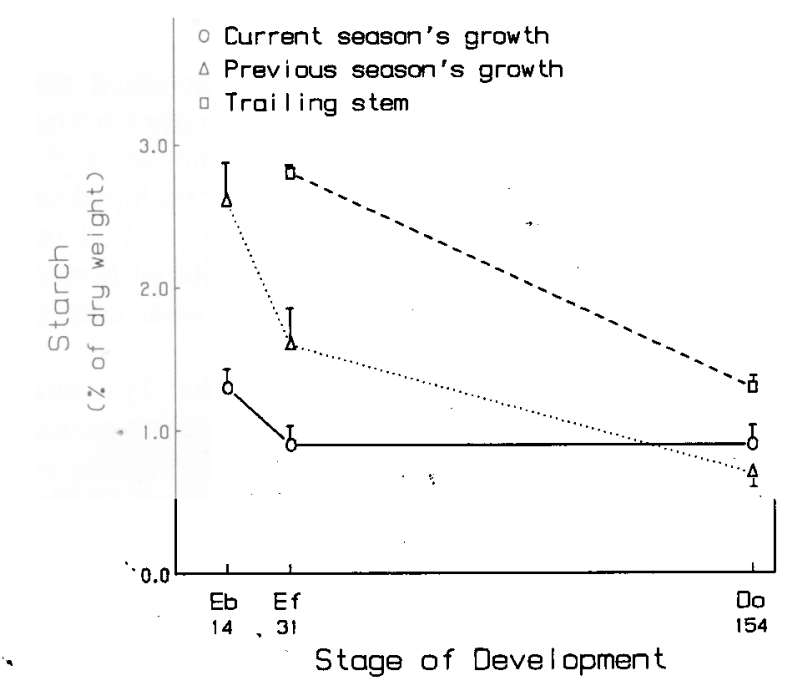

Fig. 4. Starch levels of 'Searles' cranberry uprights at three stages of development in 1988. Approximate number of days after preblossom is given for each developmental stage. Vertical bars represent SE.

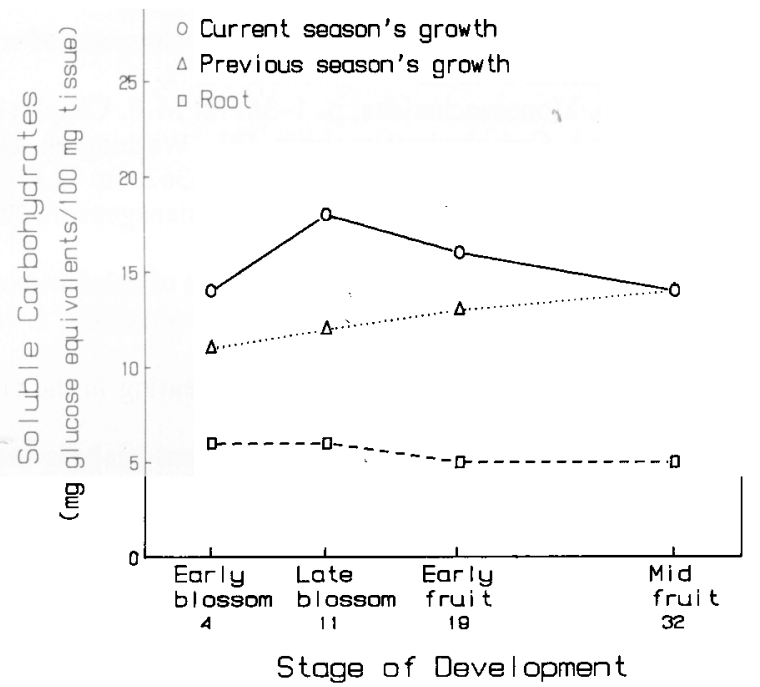

Fig. 5. Changes in the concentration of soluble carbohydrates in 'Searles' cranberry tissue grown in a greenhouse in 1988. Approximate number of days after preblossom is given for each developmental stage. Standard error bars did not exceed the size of the symbols.

developing from axillary buds on the previous season's upright growth. As the early flowers started developing into fruit, the concentration of soluble carbohydrates decreased in current upright tissue. The previous season's upright growth, including new axillary shoots, continued to increase in the concentration of soluble carbohydrates as fruit developed. Carbohydrate concentrations in root tissue were reduced only slightly as fruit developed.

Starch levels in current growth increased from $3.7 \%$ at early blossom to $5.1 \%$ at early fruit development. Compared to current growth from field uprights (Fig. 4), this represents a 3- to 5 -fold increase in the amount of starch stored. The previous season's growth plus axillary shoots contained $\approx 2.5 \%$ starch at

early blossom and early fruit development. Starch was not detected in root tissue.

\section{Carbohydrate identification}

The extract from current season's tissue at early blossom contained glucose and fructose (Fig. 6A, lanes 3 and 6), and sucrose (Fig. 6B, lanes 1 and 2) based on their co-migration with authentic sugar standards and upon their reaction with either the general reducing sugar stain (Fig. 6A, silver nitrate stain) or the fructose-specific stain (Fig. 6B, acidic urea stain). These two stains have different sensitivities for fructose, sucrose, and larger fructose-containing saccharides; hence, when both stains are employed, the presence of sucrose, faint in Fig. 6A yet more readily visualized in Fig. 6B, becomes obvious. The three slower migrating carbohydrates (polymers) present in the extract from current vegetative tissue at early blossom were readily detected with the silver nitrate stain (Fig. 6A, lanes 3 and 6) but not with the fructose-specific stain (Fig. 6B, lanes 1 and 2). One of these polymers co-migrated with the authentic standard of maltotetraose (Fig. 6A, G4). Another of the slow-migrating carbohydrates appeared to co-migrate with raffinose, but it was not detected using the fructose-specific stain (Fig. 6B, lanes 1 and 2 ), hence, its identity is uncertain. The third polymer did not co-migrate with any of the standard carbohydrates tested. This carbohydrate is not a fructan, as it was not detected with the acidic urea stain that more sensitively detects polyfructosyl oligosaccharides than does the silver nitrate stain. Trace amounts

A 123456

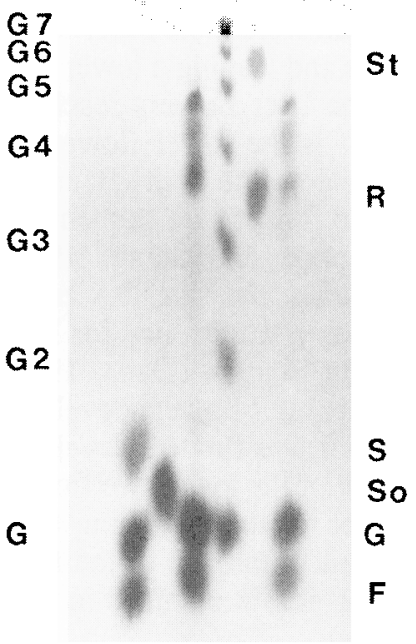

Fig. 6. Chromatography from descending paper chromatography of ethanol extracts of current season's growth of field-grown cranberry uprights. (A) Chromatogram stained with alkaline silver nitrate for detection of reducing carbohydrates. Standard sugar solutions include: lane 1-sucrose (S), glucose $(\mathrm{G})$ and fructose $(\mathrm{F})$; lane 2sorbitol (So); lane 4-maltodextrin series containing glucose (G) through maltoheptaose (G7); and lane 5-raffinose (R) and stachyose (St). Samples of an extract of cranberry tissue at the early blossom stage are in lanes 3 and 6. (B) Chromatogram stained with acidic urea for detection of fructose-containing saccharides. Standard sugar solutions include: lane 3-stachyose (St); lane 4-raffinose (R); and Lane 7-sucrose (S), glucose (not detected with this stain), and fructose (F). Samples of an extract of cranberry tissues at the early blossom stage are in lanes 1 and 2. Samples of an extract of dormant cranberry tissues are in lanes 5 and 6 . 
of raffinose and stachyose were present in current vegetative tissue at dormancy; however, the response with the fructosespecific stain was minimal and, therefore, was not readily apparent in the photograph (Fig. 6B, lanes 6 and 7). Sorbitol was not detected in tissues of either developmental stage (Fig. 6A).

\section{Fruit set}

Fruit developed from $53 \%$ of the flowers from uprights grown under greenhouse conditions. Forty-one percent of the fruit were seedless, $24 \%$ contained one to five seeds, and $35 \%$ had more than five seeds. The majority of fruit from the greenhouse contained partially developed seeds that lacked endosperm.

\section{Discussion}

A plant can be considered a collection of individual sinks that compete with each other (Wright, 1989). Whether such competition is for photosynthates, mineral nutrients, water, and/or some other growth factor is not clear. Stephenson (1981) concluded that most abortions of undamaged fruit seem to be a response to limited resources. Marucci (1966) attributed the low fruit set in cranberry to insufficient energy reserves for development of a fruit from every flower. Changing carbohydrate levels might be important since carbohydrates are involved in many aspects of plant development, including flower and fruit production. This study has demonstrated that, except at dormancy, cranberry uprights had the highest concentration of soluble carbohydrates when the lower (earliest) flowers were at anthesis, dropping by nearly one-fourth as early flowers developed into fruit and as later flowers reached anthesis or shortly thereafter. Similarly, starch levels were highest at early blossom, only to decline $30 \%$ to $38 \%$ as early flowers started developing into fruit. Early developing fruit were most likely strong sinks, thereby depleting carbohydrates and leaving a lower level of available carbohydrates by the time later flowers reach anthesis or shortly thereafter. Indeed, it is the lower flowers on an upright that are most likely to develop into fruit (Baumann and Eaton, 1986), especially when the flowers are sequentially hand-pollinated as they open (Birrenkott and Stang, 1989). Growers have long recognized that when the first flowers on the bottom of the upright set fruit, there is a tendency for laterproduced flowers higher on the upright to abort (Dana, 1990). In a recent study, only $18 \%$ of the upper later flowers developed into fruit after one or both of the earlier two flowers developed (Birrenkott and Stang, 1990). Removal of the lower two flowers from uprights allowed $45 \%$ to $58 \%$ set for the remaining flowers. Unthinned uprights developed fruit from $39 \%$ of the flowers, consistent with previous results of $\approx 38 \%$ obtained in 1986 and 1987 (Birrenkott and Stang, 1989).

Uprights grown under greenhouse conditions in solution culture had greater concentrations of carbohydrates (soluble and starch) during blossom and significantly increased fruit set than did field-grown uprights. When the time required for all flowers on an upright to undergo anthesis was shortened, as in the greenhouse, carbohydrate decreases would not be expected to occur at late blossom with the absence of developing fruit from earlier flowers. Additionally, new shoots from axillary buds on the previous season's growth, not normally produced under field conditions, unquestionably increased the amount of leaf area and dry matter per upright. That carbohydrates eventually became limiting, or an unknown factor became more limiting, is supported by the observation that, as fruit development pro- gressed in the greenhouse, the carbohydrate level did decrease and fruit set plateaued at $53 \%$.

While it may be tempting to suggest that increased carbohydrates and increased fruit set are more than simply correlated, the increase in seedless fruit, $41 \%$ in the greenhouse vs. $5.5 \%$ in the field (Rigby and Dana, 1971), partially developed seeds that lacked endosperm, and the extensive axillary bud break suggest that greenhouse-grown plants had an altered hormonal balance as well as increased carbohydrate levels when compared to field-grown plants.

In conclusion, this study has demonstrated that 1) available carbohydrates decline during the prolonged flowering period of cranberry, and 2) greenhouse-grown plants have higher carbohydrate concentrations and higher fruit set than field-grown plants. Although a causal relationship has yet to be demonstrated between carbohydrate levels and fruit set in cranberry, this study strongly supports the concept that developing fruits on the cranberry upright compete for available carbohydrates.

\section{Literature Cited}

Baumann, T.F. and G.W. Eaton. 1986. Competition among berries on the cranberry upright. J. Amer. Soc. Hort. Sci. 111:869-872.

Birrenkott, B.A. and E.J. Stang. 1989. Pollination and pollen tube growth in relation to cranberry fruit development. J. Amer. Sot. Hort. Sci. 114:733-737.

Birrenkott, B.A. and E.J. Stang. 1990. Selective flower removal increases cranberry fruit set. HortScience 25:1226-1228.

Chandler, F.B. 1952. Preliminary report on the development of cranberry fruit. Cranberries 17:6-7.

Chaplin, M.F. 1986. Monosaccharides, p. 1-36. In: M.F. Chaplin and J.F. Kennedy (eds.). Carbohydrate analysis. IRL, Washington, D.C.

Dana, M.N. 1990. Cranberry management, p. 334-362. In: G.J. Galletta and D.G. Himelrick (eds.). Small fruit crop management. Prentice-Hall, Englewood Cliffs, N.J.

DeMoranville, C.J. and K.H. Deubert. 1987. Effect of calcium-boron and manganese-zinc formulations on fruit set of cranberries. J. Hort Sci. 62:163-169.

Eaton, G.W. 1978. Floral induction and biennial bearing in the cranberry. Fruit Var. J. 32:58-60.

Eaton, G.W. and T.R. Kyte. 1978. Yield component analysis in the cranberry. J. Amer. Soc. Hort. Sci. 103:578-583.

Eaton, G. W., A.Y. Shawa, and P.A. Bowen. 1983. Productivity of individual cranberry uprights in Washington and British Columbia. Scientia Hort. 20:179-184.

Eck, P. 1986. Cranberry, p. 109-117. In: S.P. Monselise (cd.). Handbook of fruit set and development. CRC, Boca Raton, Fla.

Hawker, G.M. and E.J. Stang. 1985. Characterizing vegetative growth and fruit development in cranberry (Vaccinium macrocarpon Ait.) by thermal summation. Acts Hort. 165:311-324.

Johnson, C. M., P.R. Stout, T.C. Broyer, and A.B. Carlton. 1957. Comparative chlorine requirements of different plant species. Plant and Soil 8:337-353.

Marucci, P.E. 1966. Cranberry pollination. Cranberries 30:11-13.

Monselise, S.P. and E.E. Goldschmidt. 1982. Alternate bearing in fruit trees. Hort. Rev. 4:128-173.

Rigby, B. and M.N. Dana. 1971. Seed number and berry volume in cranberry. HortScience 6:495-496.

Stephenson, A.G. 1981. Flower and fruit abortion: proximate causes and ultimate functions. Annu. Rev. Ecol. Syst. 12:253-279.

Wise, C. S., R.J. Dimler, H.A. Davis, and C.E. Rist. 1955. Determination of hydrolyzable fructose units in dextran preparations. Anal. Chem. 27:33-36.

Wright, C.J. (cd.). 1989. Interactions between vegetative and reproductive growth. Manipulation of fruiting. Butterworths, London. p. 15-27.

Yemm, E.W. and A.J. Willis. 1954. The estimation of carbohydrates in plant extracts by anthrone. Biochem. J. 57:508-514. 